1608

\title{
低合金鋼切欠き材における繰返し過大応力と 水素侵入による疲労強度の低下*
}

\author{
山之内 隆 志*1, 近 藤 良 之*2 \\ Effects to Multiple Overloads and Absorbed Hydrogen \\ on the Fatigue Strength Reduction of Notched Component \\ Takashi YAMANOUCHI ${ }^{* 3}$ and Yoshiyuki KONDO \\ ${ }^{* 3}$ Department of Architectural Engineering, Kyushu Polytechnic College, \\ 1665-1 Shii, Kokuraminami-ku, Kitakyushu-shi, Fukuoka, 802-0985 Japan
}

\begin{abstract}
Safety is one of the most important issues in hydrogen economy. Earthquake sometimes gives damages to steel structures and machineries. The components which had not been seriously damaged would still be used after the earthquake. The residual fatigue strength of those components, however, might have been decreased. The objective of this work is to clarify the effect of relatively small number of overloads and hydrogen on the residual fatigue strength of a notched component. As a result of the experiment, it was made clear that the formation of small crack and the tensile residual stress introduced by overloads caused substantial decrease of residual fatigue limit. The test results showed that the crack depth formed by overloads was about four times deeper in hydrogen charged material. The acceleration of low cycle fatigue crack growth by overloads played a major role. The reduction of $\Delta K_{\text {th }}$ also occurred. It gave secondary contribution for the reduction of residual fatigue limit.
\end{abstract} Key Words : Earthquake, Fatigue Strength, Overloads, Notch, Hydrogen, Fatigue Crack Propaga-
tion

\section{1. 緒言}

水素利用機器の安全運用において部材の疲労強度評 価は重要な要素の1つである，地震により繰返し過大 応力を受けた機械部品のうち，壊滅的破壊に至らなか ったものはその後も継続使用されることが多いが，地 震時に受けた繰返し過大応力により微小き裂が発生し， 疲労強度が低下している場合がある(1),(2). そのため過 大応力を受けた金属材料の健全性を定量的に評価する 必要がある.また，水素利用機器では水素環境で使用 される部材の疲労強度が金属に侵入した水素により低 下することが髹念される．本研究では低合金鋼の切欠 き材を用いて少数回の繰返し過大応力を負荷した後に 高サイクル疲労試験を行い, 繰返し過大応力がその後 の疲労強度に及ぼす影響と水素の影響を検討した。

\section{2. 实験方法}

2.1 供試材および試験片供試材として低合金 鋼 SCM435H 焼入れ・焼もどし材を用いた。供試材の 化学成分を表 1 に，機械的性質を表 2 に示す. 試験片 は図1(a)に示す板状試験片を用いた。試験片には図 1(b)に示すように板厚全体にわたり，深さ $0.5 \mathrm{~mm}$ ，角

* 原稿受付 2009 年 4 月 17 日.

*1 正員, 九州職業能力開発大学校建築科 (贯 802-0985 北九州 市小勆南区志井 1665-1).

*2 正員, フェロー, 九州大学大学院工学研究院 (画 819-0395 福 岡市西区元岡 744).

E-mail : yamanouchi@ kyushu-pc.ac.jp
度 60 度, 先端半径 $0.2 \mathrm{~mm}$ の 2 次元切欠きを機械加工 により導入した。この切欠きは部品に設ける切久きと しては鋭い部類であるが，例えばねじ底等を想定し

Table 1 Chemical composition of material (mass\%)

\begin{tabular}{|c|c|c|c|c|c|c|c|c|}
\hline $\mathrm{C}$ & $\mathrm{Si}$ & $\mathrm{Mn}$ & $\mathrm{P}$ & $\mathrm{S}$ & $\mathrm{Ni}$ & $\mathrm{Cr}$ & $\mathrm{Mo}$ & $\mathrm{Cu}$ \\
\hline 0.38 & 0.18 & 0.78 & 0.15 & 0.19 & 0.08 & 1.04 & 0.15 & 0.12 \\
\hline
\end{tabular}

Table 2 Mechanical properties of material

\begin{tabular}{|c|c|c|c|}
\hline $\begin{array}{c}0.2 \% \text { proof } \\
\text { strength }(\mathrm{MPa})\end{array}$ & $\begin{array}{c}\text { Tensile strength } \\
(\mathrm{MPa})\end{array}$ & $\begin{array}{c}\text { Elongation } \\
(\%)\end{array}$ & HV \\
\hline 955 & 1048 & 19 & 344 \\
\hline
\end{tabular}

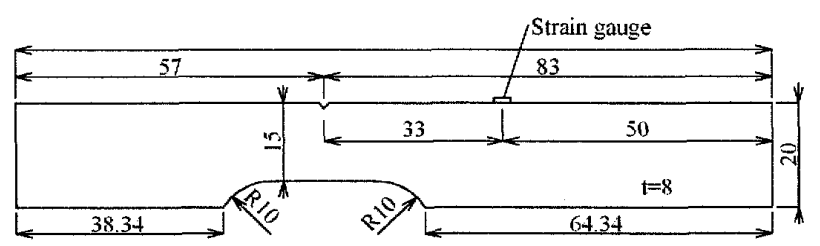

(a) Configuration

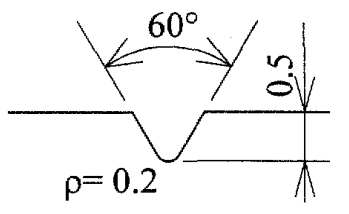

(b) Detail of notch

Fig. 1 Test specimen (Dimensions are in $\mathrm{mm}$ ) 
たものである，切欠きは加工のままで，加工後熱処理 は行っていない，負荷方式は面内曲げであり，図 1(a) に示す試験片の幅広部に貼付けたひずみゲージにより 曲げモーメントを測定し，弾性計算により曲げ応力を 算出した．応力は切欠きを考慮しない公称応力で表示 した.

2.2 過大応力負荷 図 2 に応力波形を示す. 繰返 し過大応力は周波数 $1 \mathrm{~Hz}$ により両振りで負荷した. 過 大応力の繰返し数 $n_{1}$ は $0,1,10,20,50,100,200,600$ と した．過大応力を負荷する際は切久き底に発生する残 留応力の方向性を考慮して圧縮側から除荷することに より切欠き底に引張残留応力が発生するように設定し， 安全側の結果が得られるようにした，疲労試験は室温 大気中で実施した。

2.3 高サイクル疲労試験繰返乙過大応力負荷 後の試験片に対して, 繰返し速度 $28 \mathrm{~Hz}$ で高サイクル 疲労試験を実施した。地震荷重を受けた部材は，部材 の拘束状況によっては，無負荷状態に㧁るものや，拘 束変位が残留するものなどさまざまな状況が想定され るのでこれを模擬するために図 2 に示すように外部 から負荷する平均応力 (以後外部平均応力)を $\sigma_{\mathrm{m}}=0,70$, $150,510 \mathrm{MPa} の 4$ 通りについて検討した。疲労限度は $10^{7}$ 回の繰返し後の非破断をもって定義した。

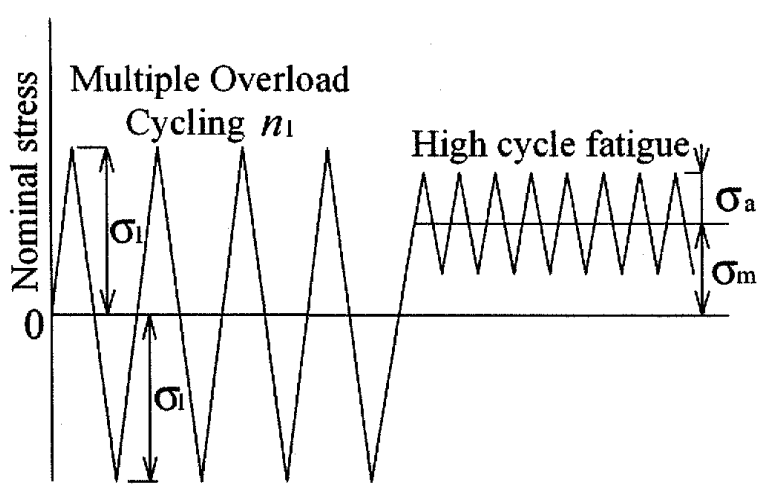

Fig.2 High cycle fatigue test after multiple overload cycling

\section{3. 繰返し過大応力試験結果と考察}

3.1 一定振幅疲学試験結果 まず種々の平均応 力下で一定振幅疲労試験を行った. $S-N$ 曲線は省略し, 図 3 に疲労限度線図を示す.

\section{2 過大応力疲労試験}

3.2.1 過大応力振幅の影響過大応力の振幅 $\sigma_{O L}$ が疲労強度低下に及ぼす影響を調べるために，種々の 過大応力振幅に対する疲労強度データを得ることとし， $\sigma_{\mathrm{OL}}=510,400,300,250 \mathrm{MPa}$ の試験を実施した。この試 験においては過大忘力負荷後の平均応力 $\sigma_{\mathrm{m}}$ は地震後
に部材に発生する最も蕨しい状態として，変位が荷重 の最大值の状態で拘束される状況を想定した $\sigma_{\mathrm{m}}=\sigma_{\mathrm{oL}}$ とした. 図 4 に $\sigma_{1}=510 \mathrm{MPa}$ の場合の過大応力負荷後の 高サイクル疲労の $S-N$ 線図の例を示す. $n_{1}$ に依存して， 疲労強度の低下が生じる.図 5 に疲労限度線図を示す。

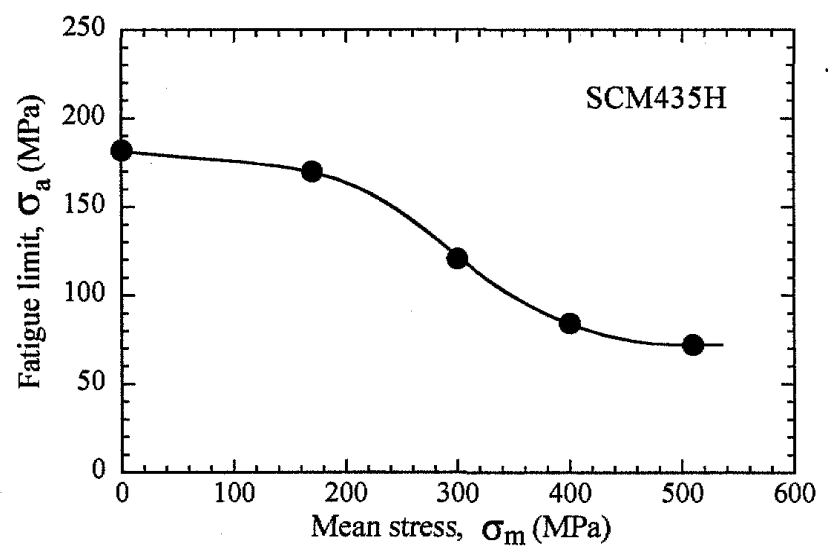

Fig.3 Fatigue limit diagram of constant stress amplitude test

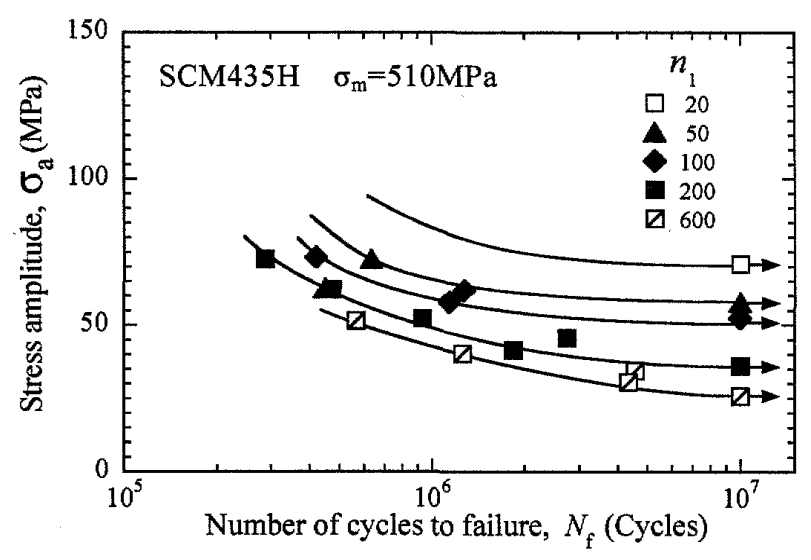

Fig.4 Fatigue strength after overload at external mean stress $\sigma_{\mathrm{m}}=510 \mathrm{MPa}$

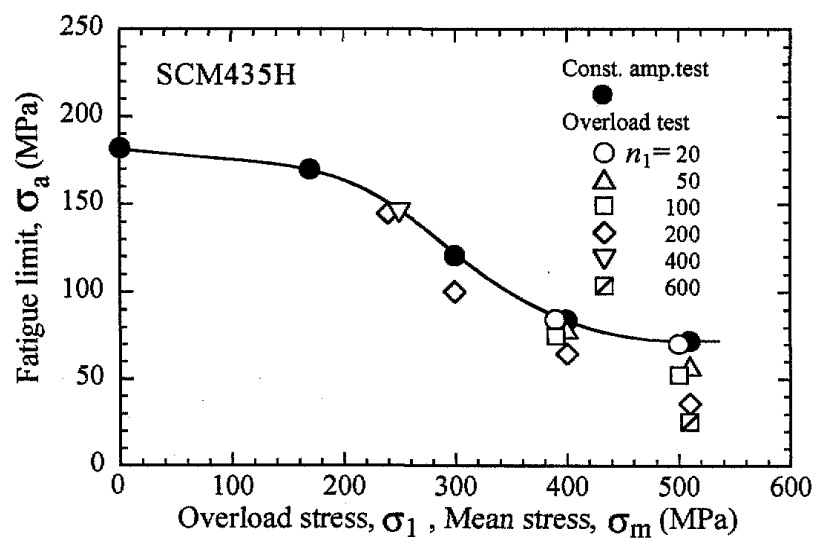

Fig.5 Effect of overload level on the reduction of fatigue strength 
過大応力を負荷していない一定振幅疲労限度を○印で 示す。過大応力を負荷した後の疲労限度を各種の白抜 き記号で示す. 過大忘力負荷後の供試材の疲労限度は 大幅に低下することが示された，過大応力の振幅 $\sigma_{1}$ が大きくかつ繰返し回数 $n_{1}$ の多い条件注ど大きく低 下した.

過大応力が振幅 $250 \mathrm{MPa}$ 以下で繰返し数が 400 回以 下の場合は疲労限度の低下隹められなかった。地震 による過大応力の繰返し数を何回と想定するかについ ては別の評価が必要であるが，大きく見積もって数百 回程度と仮定すると, その後の高サイクル疲労強度に 悪影響を与えない過大応力振幅の下限值が存在するこ とが示されている，以下にこの下限值について検討を 行った. 同じ切久き試験片を用いて実施した低サイク 儿領域の疲労破断試験（破断条件は $3 \mathrm{~mm}$ のき裂発生） を行った結果を図 6 に示す。この試験結果に基づき過 大灾力に対する累積疲労損傷值々破断 - 韭破断の関保 を評価したものを図 7 に示す。損傷值 $D$ は線形累積損 傷則により過大応力のみに対する值を求めたものであ る。

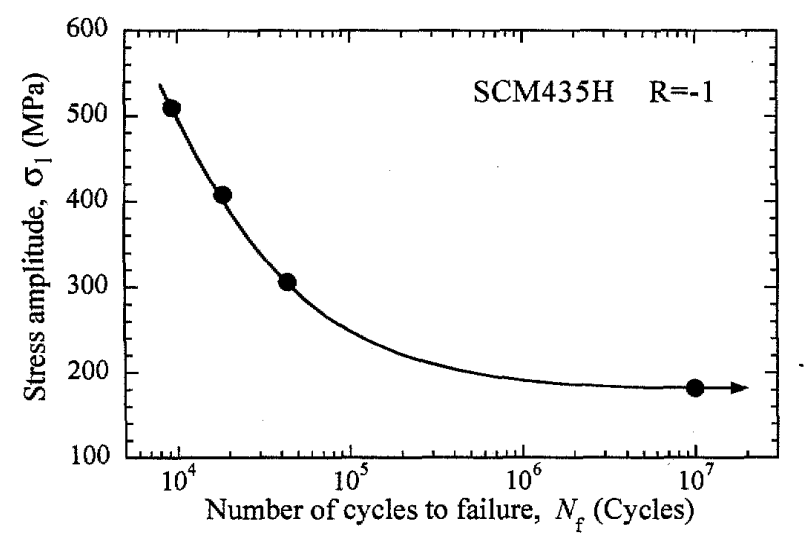

Fig.6 $S-N$ curve in low cycle fatigue region

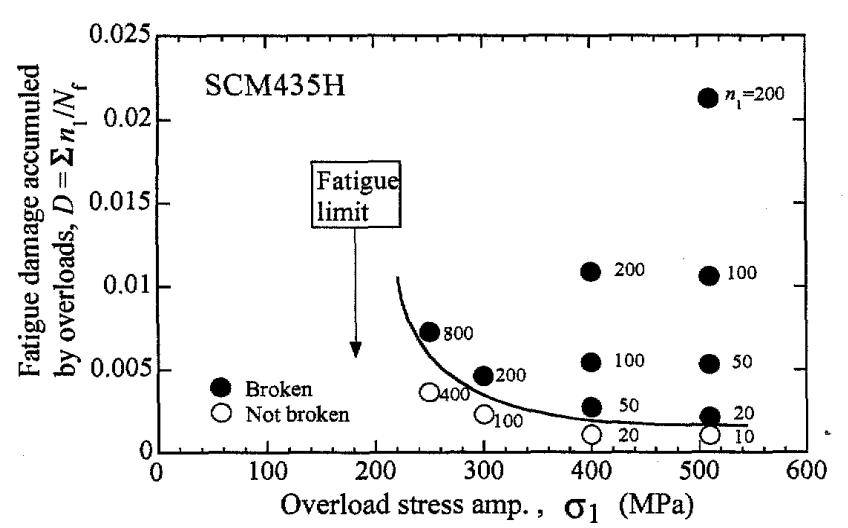

Fig.7 Linear accumulation fatigue damage that caused Reduction of fatigue limit
○印は過大応力負荷後の疲労限度が一定振幅の場合よ り低下が生じた条件を示し，○印は過大応力の影響が なかった条件を示す. 過小応力を含む実働応力の場合 に, マイナー則による損傷值の総和が最小で 0.003 程 度で生じた例が報告されている(3)。本報の結果は過大 応力のみによる疲労損傷值が 0.002 といった小さな值 でも疲労限度の低下を引起す効果が十分にあり，地震 による少数回の過大応力負荷は $S-N$ 線図に基づくマイ ナ一則の損傷值が小さいからといって軽視できない事 例のひとつである. 一方, 過大応力 $\sigma_{1}$ が低くなると境 界線は立上がり，過大応力による影響が急速に減少す る限界值が存在することが示されている。この限界值 は本報の材料と試験片では $250 \mathrm{MPa}$ であり，他の材料 や切欠き形状に対しては異なるので個々に検討評価が 必要であるが，この条件は後述する様に想定する繰返 し過大応力によって数十ミクロン程度のき裂が発生す る限界応力で, 両振り疲労限度より若干高い忘力であ る. 数百回程度の繰返し過大忘力の場合は線形累積損 傷值がおおむね 0.005 が目安となる。これにより，地 震後の機器の健全性評価において地震による応力が限 界值以下の部材については評価を除外できる可能性を 示晙する結果が得られた。

疲労限度低下の原因を検討するために, 過大応力負 荷後の高サイクル疲労試験で疲労限度となった試験片 を破面解放し，き裂の発生状況を観察した。観察され た微小き裂の例を図 8 に示す。ほぼ 2 次元の微小き裂 が観察された．SEMによる高倍率観察の結果，破面は 低サイクル疲労的であり，高サイクル疲労き裂進展し た痕跡は認められなかった。このことから，過大応力 の繰返しにより微小き裂が発生し，これがトリガーと なって高サイクル疲労強度を低下させる機構であるこ とが示された。また，疲労限度の試験片にき裂が存在 したことから，繰返し過大忘力によって発生した微小 き裂の進展限界条件が疲労限度を与えることになる。

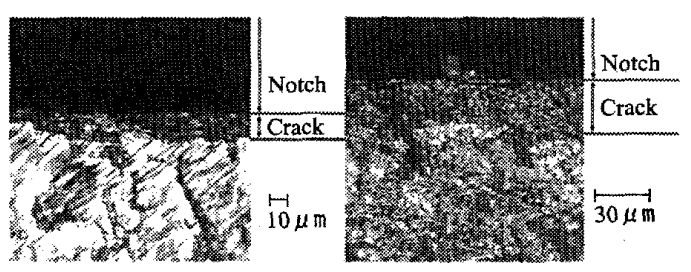

(a) 100 cycles

(b) 200 cycles

Fig. 8 Short crack formed by overload cycling $\left(\sigma_{1}=510 \mathrm{MPa}\right)$

3.2.2 過大応力負荷後の疲労限度低下に及ぼす平 均応カの影罂前項ではもっとも過酷な条件とし て，地震後に部材の変位が最大応力位置で拘束される 
ケースを想定して，高サイクル疲労の平均応力を $\sigma_{\mathrm{m}}=\sigma_{1}$ と設定した。しかし，現実的には変位が開放さ れたり，若干の変位が残留した状態で拘束されるなど のケースが想定される。そこで，そのような状況を模 擬するために外部平均応力 $\sigma_{\mathrm{m}}$ が低い領域で, $0,70 \mathrm{MPa}$, $150 \mathrm{MPa}$ の 3 種類について高サイクル疲労試験を実施 し，地震後の部材の拘束による平均応力効果を検討し た. その際の過大応力は振幅 $\sigma_{1}=510 \mathrm{MPa}$ とし, 繰返し 数 $n_{1}$ は $1,10,20,50,100,200$ とした.

図 9,10に $S-N$ 曲線の例を示す。これらの結果に基づ いて作成した疲労限度線図を図 11 に示す. 過大応力が ない一定振幅の結果をの印で, 過大応力試験の結果を 白抜き記号で示す。一定振幅の結果と比較すると過大 心力の結果は大幅に低下した，特徵として，まず過大 応力の繰返し数 $n_{1}$ がわずか 1 回でも強度低下が生じた。 1 回の過大応力では有意なき裂は発生しないので, こ の低下は過大応力急荷によって発生した引張残留応力 の影響によるものと判断される ${ }^{(4)}$. 第二の特徴は，わ

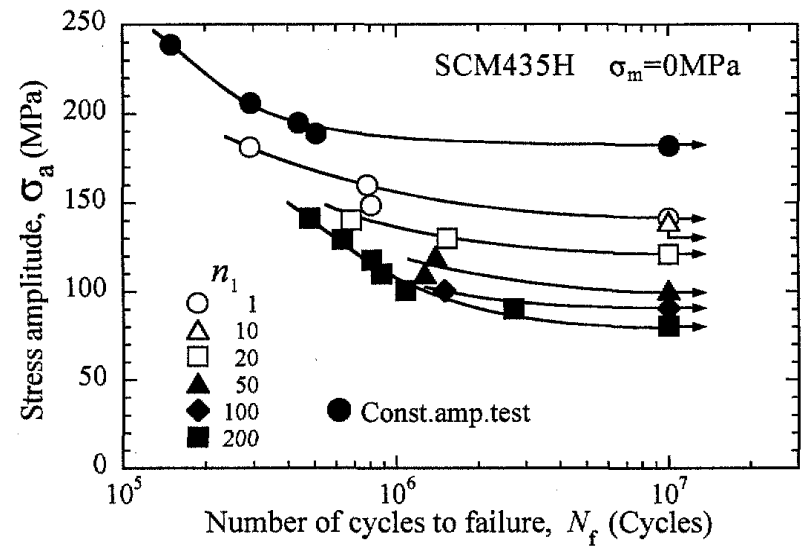

Fig.9 Fatigue strength after overload at external mean stress $\sigma_{\mathrm{m}}=0 \mathrm{MPa}$

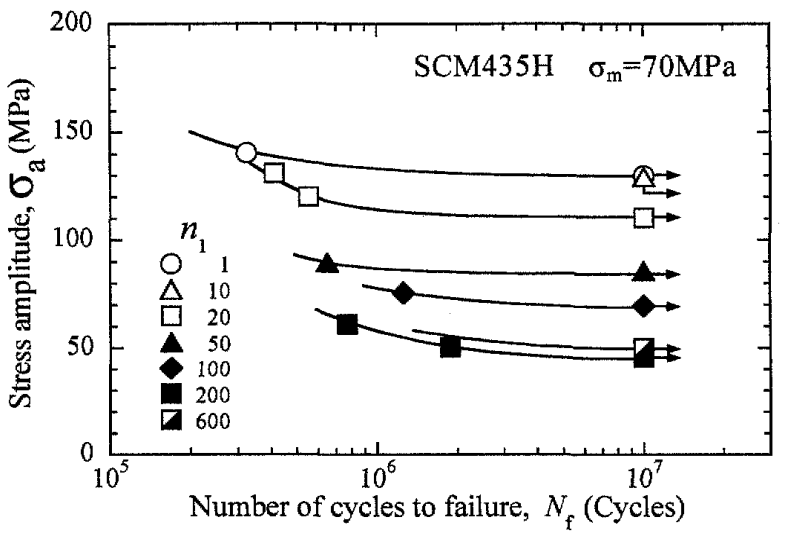

Fig.10 Fatigue strength after overload at external mean stress $\sigma_{\mathrm{m}}=70 \mathrm{MPa}$

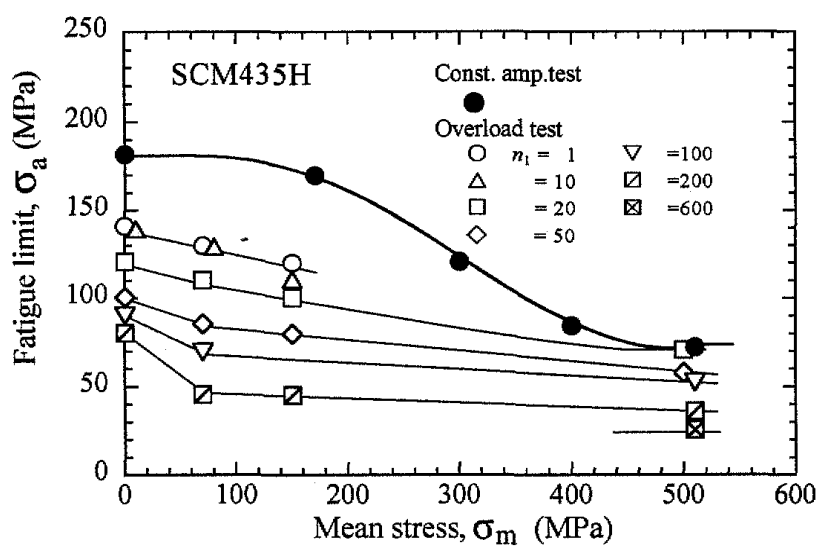

Fig.11 Reduction of residual fatigue strength after overloads shown in fatigue limit diagram

ずかな外部平均応力負荷により顕著な平均応力効果が 生じることである。過大応力負荷後の疲労限度線図は 一定振幅の場合に比べて低平均応力域で急峻に低下す る、これは過大応力により既にある程度の引張残留応 力が切欠き底に発生した上に，外部平均応力が重悳す るためである. 外部平均応力効果としては，70MPa 程 度を境にしてそれ以上ではほぼ飽和する傾向が見られ た. 本試験での最大の強度低下量は平均応力が約 $70 \mathrm{MPa}$ の場合であり，一定振幅に比べて約 $1 / 4$ にまで 低下した。大きな過大忘力を経験した部材にとって， 外部平均応力は一定振幅の場合よりも顕著な影響を有 することに注意を要する。

\section{4. 過大応力負荷後の疲労限度低下に及ぼす水素の影垶}

前章で過大応力負荷後の高サイクル疲労強度低下は 過大応力によって生成した微小き裂が主要因であるこ とが示された。水素が侵入した低合金鋼はき裂進展が 加速されることが明らかになっているので(5)，本研究 の事象に対しても水素の影響があるものと推察される。 そこで以下ではカソードチャージ法により材料内に連 続的に水素を侵入させながら疲労試験を行い，金属中 に侵入した水素が繰返し過大応力負荷後の高サイクル 疲労強度に及ぼす影響について榆討した。

4.1 連続水素チャージ法本研究の疲労試験で は $10^{7}$ 回疲労限度に到達するのに約 100 時間を要する。 しかし低合金鋼は材料中の水素の拡散速度が大きいた めに(6)，あらかじめ水素侵入させた材料を用いて室温 大気中で疲労試験する方法では, 10 時間程度で大半の 水素が放散して水素濃度が低下してしまうという不都 合がある．長時間にわたって水素濃度の低下を防ぐた めには，疲労試験中にも連続的に水素チャージを行う ことが望ましい，電解質溶液中に試験片を浸漬して連 
続的に陰分極しながら試験する方法があるが，この方 法ではき裂が電解質溶液に接触することが避けられな い，そこで，き裂を電解質溶液に接触させないように しつつ，かつ連続的に陰分極により水素チャージする 方法として著者の一人が先に考案した以下の方法 ${ }^{(7)}$ 採用した。

陰分極による連続水素チャージ法の概略図を図 12 に示す. 試験片の切久き部は耐水性の接着剤を用いて 切欠きから $2 \mathrm{~mm}$ 下までの範囲をコーティングし,電解 質とき裂の接触を防止した，電解質溶液を保持する容 器を供試材に取り付け，対極として白金板を用いてガ ルバノスタットにより陰分極を行った。き裂から少し 離孔た場所で水素を発生させ，侵入した水素が試験片 内部を拡散してき裂部分に到達するという方法である。 溶液は室温の $\mathrm{pH}=2.0$ の希硫酸を使用し，電流密度は $130 \mathrm{~A} / \mathrm{m}^{2}$ とした。疲労試験を開始する前にあらかじ 48 時間水素チャージを施して水素濃度を高めた後, 連 続チャージしながら繰返し過大応力を負荷し, その後 高サイクル疲労試験に移行した。

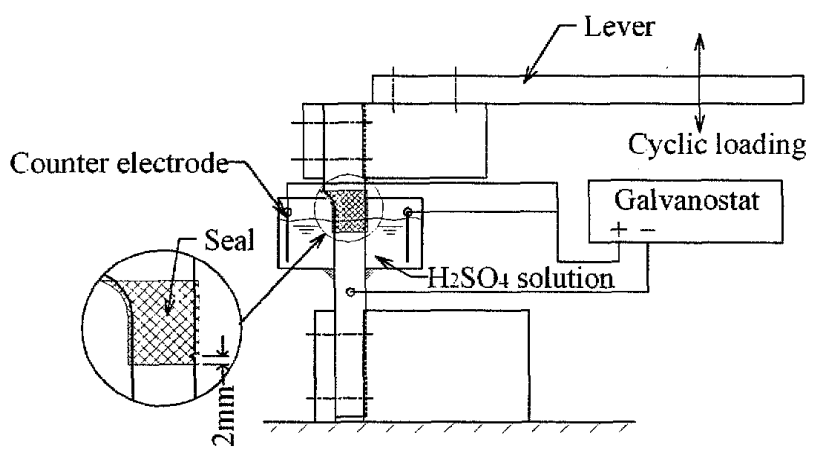

Fig.12 Continuous cathodic polarization method

4.2 水素チャージ下の過大応力疲学試験結果 過大応力は両振りで振幅 $\sigma_{1}=510 \mathrm{MPa}$ とし, 外部から負 荷する高サイクル疲労の平均応力を $\sigma_{\mathrm{m}}=70 \mathrm{MPa}$ と $510 \mathrm{MPa}$ の 2 種類について試験を行った. 過大応力繰 返し数 $n_{1}$ は 10,20,50,100,200 回とした. 試験結果の $S-N$ 線図を図 13,14 に示す. 白抜き印は未チャージを 示し，黑印は水素チャージの試験結果を示す，図 13 は平均応力 $\sigma_{\mathrm{m}}=70 \mathrm{MPa}$, 図 14 は平均応力 $\sigma_{\mathrm{m}}=510 \mathrm{MPa}$ の $S-N$ 曲線である. 図 15 に疲労限度線図を示す. 過大 応力のない一定振幅の疲労限度線図と比較すると, 過 大応力負荷を経験した部材の疲労強度は著しく低下し， 本来の強度とは大きく異なる強度特性になっているこ とに注意が必要である。たとえば，両振り条件で設計 された部材は本来 $180 \mathrm{MPa}$ の禹振り疲労限度を有する が，水素環境下で $510 \mathrm{MPa}$ の過大応力が 100 回負荷さ
れた上にわずか $70 \mathrm{MPa}$ の外部引張平均応力が残留す ると, 疲労限度は約 $1 / 5$ の $40 \mathrm{MPa}$ にまで低下すること になる。

平均応力 $\sigma_{\mathrm{m}}=70 \mathrm{MPa}$ の過大応力の繰返し数と疲労限

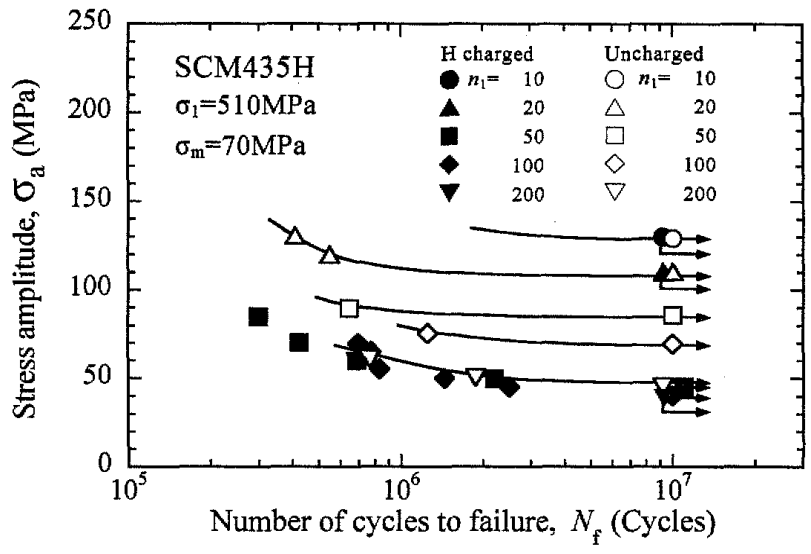

Fig.13 Effect of absorbed hydrogen on the reduction of fatigue strength after overloads $\left(\sigma_{\mathrm{m}}=70 \mathrm{MPa}\right)$

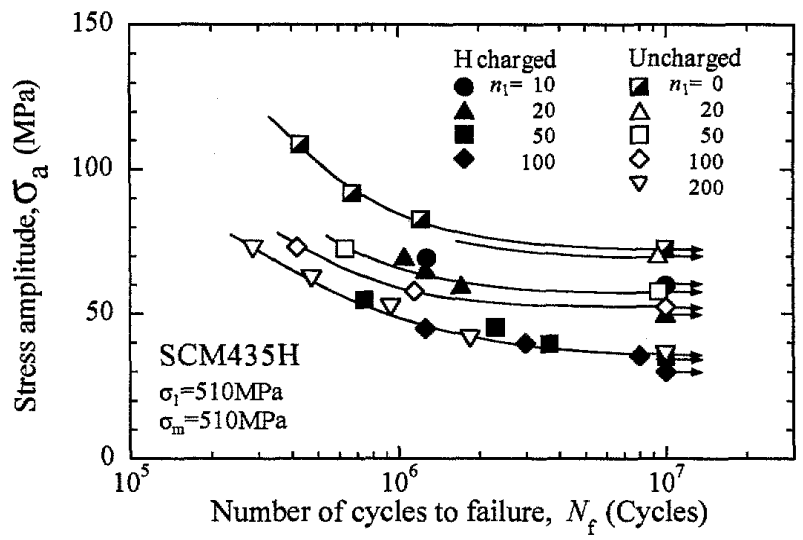

Fig.14 Effect of absorbed hydrogen on the reduction of fatigue strength after overloads $\left(\sigma_{\mathrm{m}}=510 \mathrm{MPa}\right)$

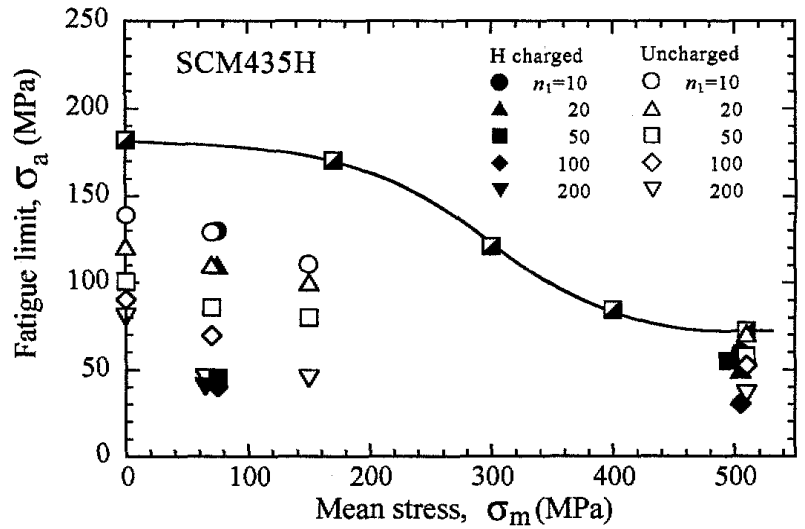

Fig.15 Effect of absorbed hydrogen on the reduction of fatigue limit diagram after overloads $\left(\sigma_{1}=510 \mathrm{MPa}\right)$ 
度の関係を図 16 に示す. 過大応力の繰返し回数の増加 とともに疲労限度の低下量が増大する。平均応力 $\sigma_{\mathrm{m}}=510 \mathrm{MPa}$ 時の過大応力の繰返し数と疲労限度の関 係を図 17 に示す. $500 \mathrm{MPa}$ 程度の過大応力が 10 回程 度以上負荷されると, 高サイクル疲労強度低下が生じ 始めることが示されている。

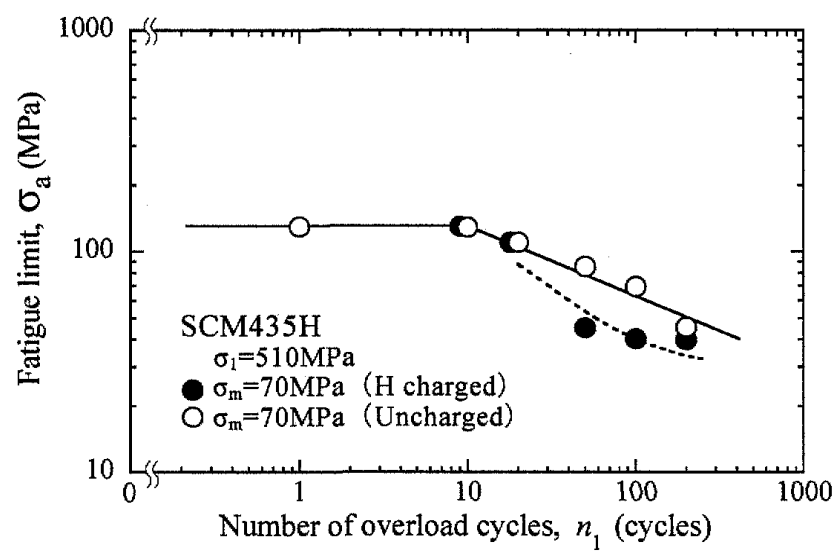

Fig.16 Effect of overload cycle and hydrogen on the reduction of fatigue limit $\left(\sigma_{\mathrm{m}}=70 \mathrm{MPa}\right)$

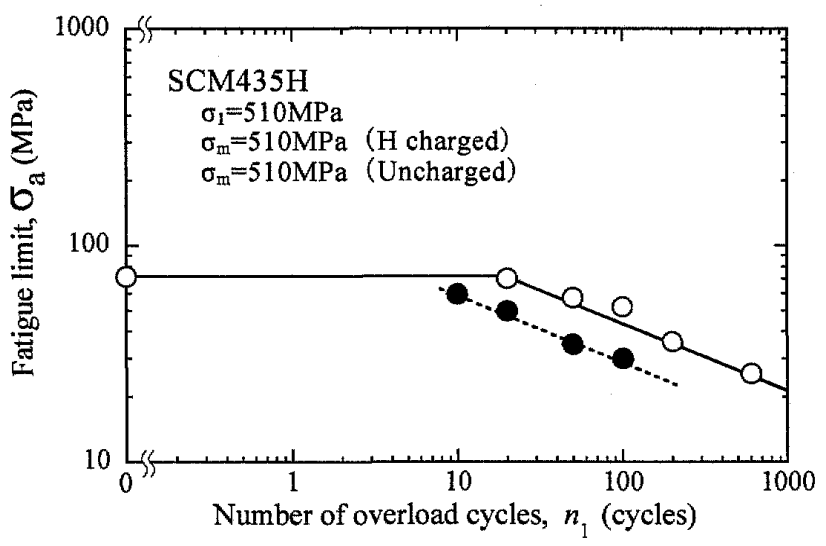

Fig.17 Effect of overload cycle and hydrogen on the reduction of fatigue limit $\left(\sigma_{\mathrm{m}}=510 \mathrm{MPa}\right)$

4.3 水素の影響の原因についての検討結果水 素侵入による疲労限度の低下の原因については仮説と して次の二点があげられる. 一点目は水素により繰返 し過大応力で発生するき裂が深いことであり, 二点目 は高サイクル疲労き裂進展の下限界条件が低下するこ とである。これらのうちいずれが優勢な因子であるの かを確認するために，一点目に対する検証として，末 チャージ材と水素チャージ材の双方に対して疲労限度 の試験片を破面解放してき裂長さを測定した。き裂梁 さの測定結果を図 18 に示す.○印で示す未チャージ材 に対して，○で示す水素チャージ材の場合は約 4 倍と

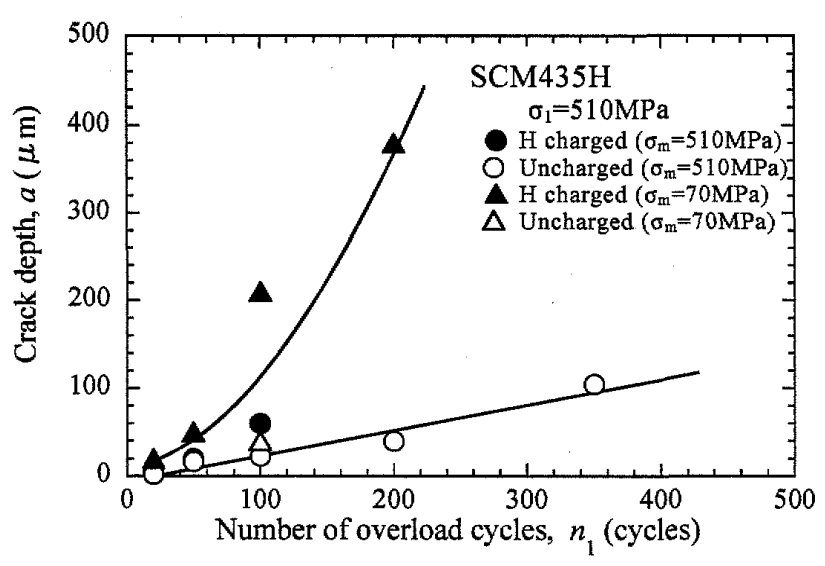

Fig. 18 Depth of non-propagating crack in fatigue limit specimen after overload

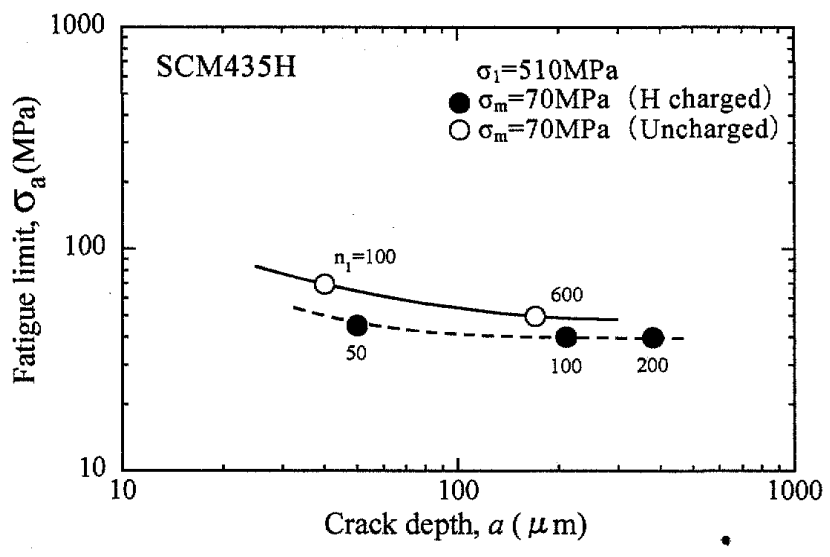

Fig.19 Effect of crack depth on the reduction of residual fatigue limit

格段にき裂が低く，大きな要因であることが確認され た.

次に二点目に対する検証として，繰返し過大応力に よって発生したき裂梁さと高サイクル疲労限度の関係 を図 19 に示子. ○印が未チャージ材，○印が水素チャ 一ジ材の結果を示す. 水素チャージ材の疲労限度は未 チャージ材の疲労限度より約 $20 \%$ 低い。この低下量は 先の研究 ${ }^{(8)}$ で微小き裂材の疲労き裂進展下限界条件 $\Delta K_{\mathrm{th}}$ に及ぼす侵入水素の影響を調べた結果とほぼ一 致している．侵入水素による $\Delta K_{\text {th }}$ の低下は生じるが， その寄与は比較的軽微である。なお，同図の曲線の勾 配が Kitagawa-Takahashi ダイアグラム( ${ }^{(9)}$ の 0.5 とは異 なるが,これは過大応力によって発生した引張残留応 カがき裂が染くなるにつれて徐々に解放され，き裂が 深いほど有効な応力比が低下することによると推定さ れる。

以上の検討から, 繰返し過大応力後の高サイクル疲 労強度低下に及洔す水素の影響としては，二つの要素 
とも寄与するが，前者の過大応力によるき裂成長が加 速される効果の方が優勢な因子であると結論される.

\section{5. 結}

低合金鋼 SCM435H の切久き試験片を用いて, 繰返 し過大応力負荷によるその後の高サイクル疲労強度低 下およびそれに及ぼす水素侵入の影響を検討した，得 られた結果は以下の通りである。

（1）ある限界值以上の繰返し過大応力が負荷される と, その後の高サイクル疲労強度は低下する. その主 要原因は，切欠き底に発生する引張残留応力と，繰返 し過大応力により発生した微小き裂が高サイクル疲労 き裂成長のトリガーになることである.

（2）過大応力を経験した部材の疲労強度は著しく低 下し，本来の強度とは異なる強度特性になっており， わずかな外部引張応力の存在で, 著しい疲労強度低下 を生じる。

（3）過大応力振幅がある限界值以下では過大応力の 影響がないので，これらの部材では地震後の健全性評 価で評価を除外できる可能性が示唆された。

（4）水素により過大応力負荷後の疲労強度低下はさ らに助長される，その主要因は繰返し過大応力により 未チャージ材と比較して格段に深いき裂が生成される ためである。また，疲労き裂進展下限界特性の低下も 生じるが、これは二次的な寄与である。

\section{文献}

(1) K.Okuya and Y.Kondo, The Effect of Large Strain Cycling on the Fatigue Strength of Welded Joint, Journal of ASTM International, Vol.3, No.4, Paper ID. JAI 13232 (2006), pp.1-11.
(2) Y.Kondo and K.Okuya, The Effect of Seismic Loading on the Fatigue Strength of Welded Joint, Materials Science and Engineering A, 468-470 (2007), pp.223-229.

(3) H.Nakamura, Summary of fatigue experiments under service loading, Journal of JSME, Vol. 73 (1970), pp.1350-1358.

(4) R.I.Stephens, A.Fatemi, R.R.Stephens, H.O.Fuchs, Metal Fatigue in Engineering 2nd edition, John Wiley \& Sons, Inc., (2001), p.277.

(5) K.Yanagihara, S.Ohyanagi, M.Kubota, C.Sakae and Y.Kondo, Effects of Crack Size, Stress Ratio and Hydrogen on the Near Threshold Fatigue Crack Propagation of High Strength Steel, Journal of Materials Science, Japan, Vol.54 (2005), pp.1237-1243.

(6) Y.Fukai, et al., Suiso to kinzoku, Uchida-roukakuho, (2002).

(7) Y.Kondo, M.Kubota and K.Shimada, Crack Propagation Behavior of SCM440H Low Alloy Steel Enhanced by Hydrogen under Long-term Varying Load and Static Load, Transactions of the Japan Society of Mechanical Engineers, Series A, Vol.75, No.754 (2009), pp.752-760.

(8) Y.Kondo, M. Kubota, K.Shishime and J.Yamaguchi, Transactions of the Japan Society of Mechanical Engineers, Series A, Vol.74, No.746 (2008), pp.1366-1372.

(9) H.Kitagawa and S.Takahashi, Applicability of fracture mechanics to very small cracks or the cracks in the early stage, Proc. of 2nd ICM, Cleveland (1976), pp.627-631. 